\title{
Estradiol, progesterone, testosterone profiles in human follicular fluid and cultured granulosa cells from luteinized pre-ovulatory follicles
}

\author{
Xuesong Wen ${ }^{1,2,3}$, Dong Li ${ }^{1,2,3}$, Amanda J Tozer ${ }^{2}$, Suzanne M Docherty ${ }^{1,2}$, Ray K lles ${ }^{1,2^{*}}$
}

\begin{abstract}
Background: The production of sex steroids by follicular cells is proposed to be influenced by the maturity of the incumbent oocyte. Thus steroid levels may reflect suitability of an oocyte for IVF. We examined follicular fluids and granulosa cell production of steroid from IVF patients in order to test the relationship between steroid levels and fertilization.
\end{abstract}

Methods: Follicular fluid and granulosa cells were extracted from 206 follicles of 35 women undergoing controlled ovarian stimulation. Follicular fluid was assayed for estradiol, progesterone and testosterone. Granulosa cells were cultured from individual follicles and their culture media assayed for production of these hormones after 24 hrs in vitro. Levels of steroids were correlated with follicular diameter, oocyte recovery and subsequent fertilization.

Results: Follicular fluid levels of progesterone were 6100 times higher than that of estradiol, and 16,900 times higher that of testosterone. Despite the size of follicle triggered after controlled luteinisation, the levels of progesterone and testosterone were maintained at relatively constant levels (median 98.1 micromoles $/ \mathrm{L}$ for progesterone, and 5.8 nanomoles/L for testosterone). However, estradiol levels were slightly lower in the larger follicles (follicular diameter 10-15 mm, median 25.3 nanomoles/L; follicles $>=15 \mathrm{~mm}$, median 15.1 nanomoles/L; linear correlation $r=-0.47, p<0.0001$ ). With respect to oocyte recovery, no steroid showed a significant association in follicular fluid levels. Similarly no difference in follicular fluid steroid levels was found for those oocytes that did or did not fertilize. Significant quantities of progesterone were produced by the granulosa cells but production was constant regardless of the size of follicle from which the cells originated. Estradiol levels were only detectable in 10 of 121 cultures examined, and testosterone in none. Interestingly, when an oocyte was present follicular estradiol levels correlated with progesterone levels. However, when absent, follicular estradiol levels correlated with testosterone levels but not with progesterone.

Conclusions: The principle steroid product of luteinized pre-ovulatory granulosa is progesterone, a differentiation triggered by the gonadotropin surge. However, absolute steroid levels are associated with follicular size, not oocyte maturation/ability to fertilize.

\section{Background}

Oocyte maturation is a complex process that includes the re-initiation and completion of the first meiotic division and subsequent progression to metaphase II, as well as nurse cell preparation of the oocyte cytoplasm. As the whole process of nuclear and cytoplasmic change is crucial for fertilization and early embryo development,

\footnotetext{
*Correspondence: r.iles@mdx.ac.uk

'Biomedical Sciences, School of Health and Social Science, Middlesex University, The Burroughs, NW4 4BT, UK

Full list of author information is available at the end of the article
}

investigations have concentrated on the composition of the intercellular environment of this process, the follicular fluid.

Estradiol, progesterone and testosterone are the main steroid hormones that play essential roles during the follicular and luteal phases of the menstrual cycle. However other cytokines, such as inhibins, activins, insulin growth factor-2, insulin growth factor binding proteins, tumour growth factor- $\beta$ and endothelial growth factor, have been measured in follicular fluid and correlated with oocyte maturation [1-4]. Nevertheless, only serum

\section{() Biomed Central}


concentrations of estradiol and follicular size are routinely used for monitoring follicular development and oocyte maturity during ovarian induction for assisted reproduction [5-8].

Despite this, there are still inconsistencies in the literature regarding estradiol and the other steroid hormone concentrations in follicular fluids, and also in granulosa cell cultures. There is even less information on steroid secretion profiles of granulosa cells cultured from individual follicle. Ryan and Smith carried out the first study of the biosynthesis capability of the human ovarian follicle in 1961 [9,10]. They showed that apart from estradiol and estrone, there were also some androgens and progesterone produced. However, this experiment was compromised by the fact that they incubated the cells in the presence of progesterone because a prevailing hypothesis claimed that this was a necessary extrinsic precursor of granulosa/theca estrogen synthesis. In an earlier study on rat follicles, Falck [11] had noted that both theca and granulosa cells that were necessary for oestrogen biosynthesis result from an interaction of the two cell types. However, Channing and Coudert [12] showed that monkey theca cells alone were able to produce normal amount of estrogens. Thus they concluded that theca cells were the main producers of estradiol rather than granulosa cells. This is completely different from the accepted 'two-cell, twogonadotropin' theory of follicular steroidogenesis which is found in multiple texts. According to this theory, granulosa cells are the main source of estradiol production, which results from conversion of theca cell-derived androgens $[13,14,2]$. This is largely based on reports that aromatization is stimulated by FSH, whose activity can only be activated by binding to its receptor on granulosa cells [2]. Indeed, it is commonly accepted that theca cells produce progesterone rather than estradiol due to this lack of aromatase (CYP19) activity [15,2].

This study set out to investigate the levels of estradiol, progesterone and testosterone found in individual follicular fluid from stimulated cycles and their granulosa cell cultures after oocyte retrieval. The principal aim was to investigate steroid hormone levels in relationship to follicular diameter, oocyte presence and subsequent fertilization. However, this also allowed us to investigate steroidogenesis within the ovarian-follicular environment following stimulation for IVF, a situation akin to a follicle after the gonadotropin surge.

\section{Methods}

\section{Patients}

35 patients who undertook In Vitro Fertilization/Intracytoplasmic Sperm Injection at the Fertility Unit of St Bartholomew's Hospital from 1999 to 2001 were recruited into this study. The ages of patients varied from 29 to 38 years old, and the follicular size varied from $10.2 \mathrm{~mm}$ to $35 \mathrm{~mm}$. The total number of the follicles sampled was 206; 4 to 6 follicles per patient. The causes of infertility in this patient cohort were male, tubal or unexplained factors. Patients with endometriosis and polycystic ovarian syndrome were excluded from this study, as ovarian steroid hormone production is known to be altered in these conditions. Due to blood contamination, limited sample volume and lack of follow-up information, the final distribution of sample numbers between oocyte recovery, fertilization outcome and steroid analysis is shown in figure 1.

Written consent was obtained from each patient, and this study was approved by the East London and The City Health Authority Research Ethics Committee (study number: P/98/222).

\section{Sample collection}

Sample collection was 36 hours after subcutaneous administration of human chronic gonadotropin [10,000 IU (Profasi, Serono)], and when at least three follicles in each patient had reached $18 \mathrm{~mm}$ in diameter as measured by ultrasound scan (Hitachi, model EUB-525, Northants, UK). Individual follicles were randomly selected prior to aspiration and measured in two dimensions by transvaginal ultrasound in order to obtain a mean diameter. The same operator performed all measurements and aspirations. Following identification of a suitable follicle, the follicle was gently pierced using a double lumen needle and aspirated, allowing the follicle to collapse slowly around the needle. The follicle was then flushed with $4.5 \mathrm{ml}$ of heparinised saline $(3 \times 1.5 \mathrm{ml}$ automated flushes $)$ and aspirated again. Heavily blood stained aspirates were discarded and a further follicle was measured and aspirated if appropriate. A detailed record was kept of the volume of fluid aspirated per individual follicle prior to washing. Following examination of the follicular fluid, it was placed in a sterile tube and the presence of an oocyte was noted and recorded. If an oocyte was not retrieved, the follicle was flushed again with an additional $3 \mathrm{ml}$ heparinised saline. If an oocyte was still not obtained, the follicle was recorded as having no oocyte retrieved. Then the follicular fluids were taken immediately to the Williamson Laboratory. Each tube was centrifuged at $200 \times g$ for 10 minutes to precipitate harvested granulosa cells. Follicular fluid supernatant was aspirated, divided into aliquots, and frozen at $-20^{\circ}$ $\mathrm{C}$ for subsequent hormone analysis. The fertilization outcome was also recorded according to the appearance of two pro-nuclei after incubating in cultured medium after 48 hours.

\section{Isolation and culture of granulosa cells from individual follicles}

Harvested follicular fluid cell pellets were resuspended in $4 \mathrm{ml}$ of medium. This consisted of RPMI-1640 with 


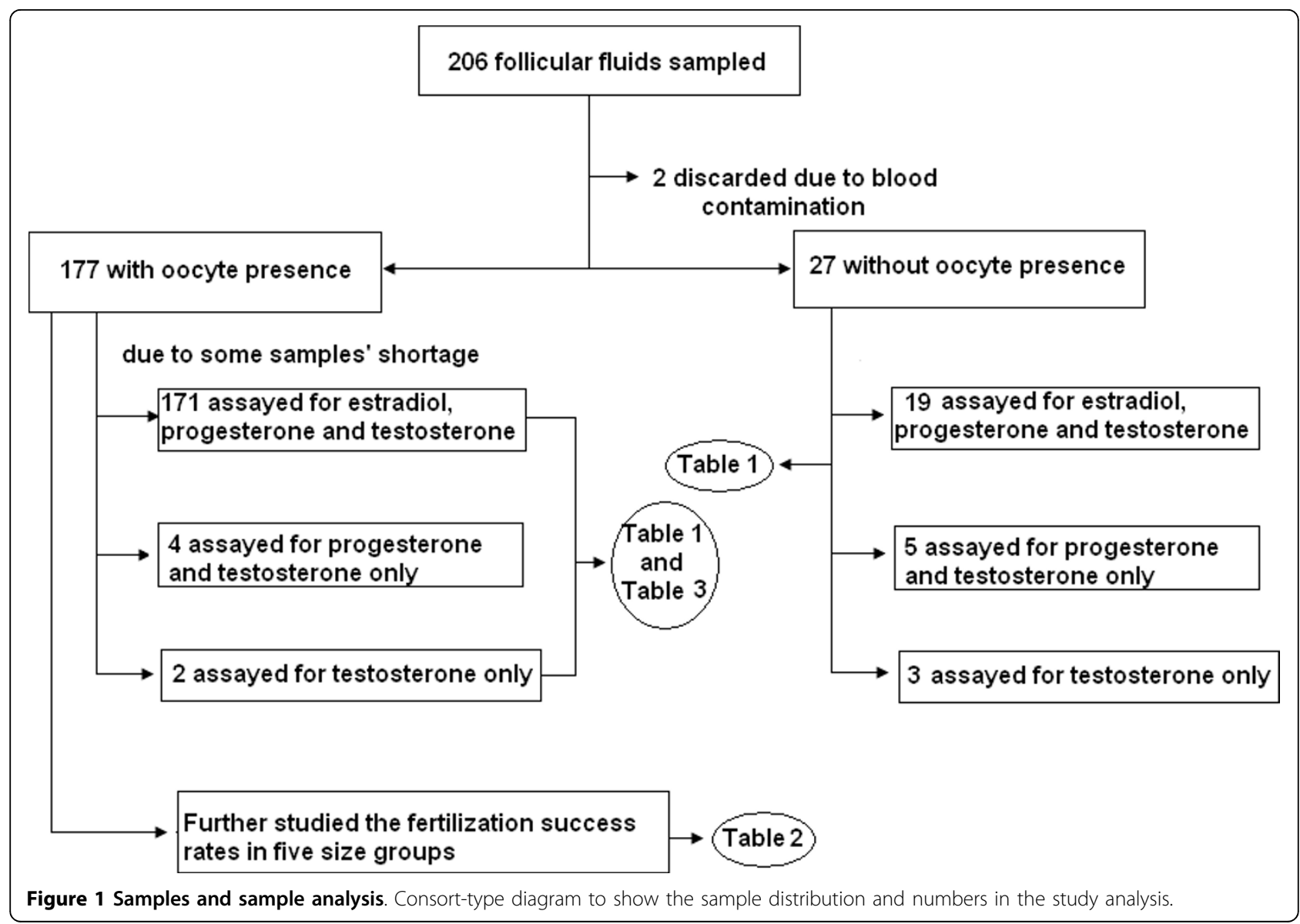

glutamine and $\mathrm{NaHCO}_{3}$ [Sigma, Poole, UK] supplemented with $10 \% \mathrm{v} / \mathrm{v}$ fetal calf serum (FCS) [GibcoBRL, Paisley, UK] and $1 \% \mathrm{v} / \mathrm{v}$ of an antibiotic stock solution containing 10,000 $\mu \mathrm{g} / \mathrm{ml}$ Penicillin G sodium and $25 \mu \mathrm{g} /$ $\mathrm{ml}$ Streptomycin [GibcoBRL, Paisley, UK]. After washing and re-centrifugation at $200 \times g$ for 10 minutes, cells were resuspended in $5 \mathrm{ml}$ of medium containing $0.2 \%$ hyaluronidase (80IU/ml. Medicult, UK) for cell dispersion, and then incubated at $37^{\circ} \mathrm{C}$ for 30 minutes. After this time, the sample was again centrifuged at $200 \times \mathrm{g}$ for $10 \mathrm{~min}$ utes and the cell pellet resuspended with $2 \mathrm{ml}$ of medium and layered over $4 \mathrm{ml}$ of 50\% Percoll [Pharmacia, Amersham, UK]. This was centrifuged at $250 \times g$ for 20 minutes to separate the luteinized granulosa cell buffy coat from any contaminating erythrocytes. The granulosa cells were removed using a pipette and washed with $8 \mathrm{ml}$ of medium. After a final centrifugation at $250 \times g$ for 10 minutes the pellet was resuspended and the cell number was determined using a haemocytometer. Cells were then plated, in triplicate wells, at a concentration of 10,000 cells per well in 24 well culture plates (Corning, NY, USA) and incubated at $37^{\circ} \mathrm{C}$ in a $95 \%$ air, $5 \%$ $\mathrm{CO}_{2}$ humidified environment for 24 hours and the cell free supernatant media was then collected and stored at $-20^{\circ} \mathrm{C}$ for later analysis.

\section{Steroid measurement}

Steroid hormone levels of progesterone, estradiol and testosterone were measured in follicular fluid and culture media by radioimmunoassay (RIA). These assays were carried out by commercial kits provided by Skybio Limited (Bedford, UK).

Testosterone - The minimum detection of this essay was $0.2 \mathrm{nmols} / \mathrm{L}$, and its standard range was from 0.7 nmols/L to $69 \mathrm{nmols} / \mathrm{L}$. The cross reaction of this assay is reported to be lower than $0.01 \%$ for androstenedione, dihydroxytestosterone, estrone, estradiol- $17 \beta$ and progesterone. Quality control data from repeat assays showed $<10 \% \mathrm{CV}$.

Estradiol - The minimal detectable concentration was 25 pmols/L, and its standard range was from $37 \mathrm{pmols} / \mathrm{L}$ to $11,100 \mathrm{pmols} / \mathrm{L}$. The cross reactivity of this assay is reported to be: estrone $<6.2 \%$, estradiol $<1.5 \%$, cholesterol, DHEA, $17 \alpha$-Hydroxyprogesterone, pregnenolone, progesterone and testosterone all lower than $0.01 \%$. Quality control data from repeat assays showed $<15 \% \mathrm{CV}$. 
Progesterone- The minimum detectable concentration was $4 \mathrm{nmols} / \mathrm{L}$, and its standard range was from $5 \mathrm{nmols} /$ $\mathrm{L}$ to $80 \mathrm{nmols} / \mathrm{L}$. Consequently samples needed to be diluted between 10 and 100 fold. The cross reactivity of this assay is reported to be: $17 \alpha-$ Hydroxyprogesterone $<0.5 \%$, pregnenolone $<0.3 \%$, testosterone, estradiol $-17 \beta$, cholesterol all $<0.001 \%$. Quality control data from repeat assays showed $<8 \% \mathrm{CV}$.

\section{Statistical analysis}

Data was tabulated in Excel and imported in to a data analysis software StatsDirect package (StatsDirect Ltd, Cheshire, UK) and a p $<0.05$ was taken as statistical significance. Graphical analysis was initially conducted as scatter plots where the concentrations and calculated total content of the steroid hormones were plotted against its individual follicular diameter and correlations tested. Distribution analysis revealed that the data generated had a non-Gaussian distribution; consequently, non-parametric statistical description and statistics have been used. Spearman rank correlation analysis was used to compare the inter-relationship between the examined steroids.

\section{Results}

\section{Steroid levels in follicular fluid}

For all follicular fluid samples, estradiol concentrations varied from $2.2-130.0 \mathrm{nmoles} / \mathrm{L}$ (median $=16.1$ nmoles/L). Levels significantly decreased as follicular size increased (figure $2 \mathrm{a}: \mathrm{r}=-0.47, \mathrm{p}<0.0001$ ). A sharp decrease in estradiol concentration was indicated between 10 and $20 \mathrm{~mm}$ follicle diameter, and a plateau concentration was seen for follicles $\geq 20 \mathrm{~mm}$ in diameter. However, when corrected by follicular volume, the total follicular content of estradiol increased with follicular diameter (figure 2b: $\mathrm{r}=0.79, \mathrm{p}<0.0001$ ).

Testosterone concentration varied from $0.3-110.0$ nmoles $/ \mathrm{L}($ median $=5.8 \mathrm{nmoles} / \mathrm{L})$. The general trend was for testosterone concentration to remain constant despite follicular size (figure 3a). Consistent with this finding was that total testosterone content within each individual follicle increased with the size of the follicle (figure 3b: $\mathrm{r}=0.52, \mathrm{p}<0.0001$ ). Progesterone concentration varied from 1.1-1255.0 $\mu$ moles $/ \mathrm{L}$ (median $=98.1$ $\mu$ moles/L). Although the general trend was for progesterone concentration to remain constant despite follicular size (figure $4 \mathrm{a}$ ), the total progesterone content of the follicles correspondingly increased (figure $4 \mathrm{~b}: \mathrm{r}=0.64$, $\mathrm{p}<0.0001$ ).

\section{In vitro secretion of steroids by cultured luteinized granulosa}

All three steroid hormone levels were measured at 24 hours in culture media taken from granulosa cells isolated from individual follicles, and grown in triplicate. Testosterone was not detected in any of the 110 granulosa cell cultures examined. Only 10 out of 121 granulosa cell cultures examined contained detectable levels of estradiol production $(15,15,16,65,77,88,108,150$, 152, 489 pmoles/L/10,000 cells/24 h). Significant levels of progesterone production were detected in all 104 granulosa cell cultures examined (median value was 409 nmoles/L/10,000 cells/24 h; inter-quartile range 247-925 nmoles/L/10,000 cells/24 h). Progesterone production by granulosa cells was relatively constant and did not correlate with the diameter of the follicle from which they originated (data not shown).

\section{Relationship of steroid hormone levels with oocyte presence and fertility outcome}

There was no significant difference in progesterone production at 24 hours in cultured medium between the groups with or without an oocyte present. Similarly, the follicular fluid concentration of all three steroids showed no statistically significant difference between follicles from which an oocyte was or was not recovered. This was despite a general trend of lower median levels of testosterone in the group from which an oocyte was recovered (see table 1). For the recovered oocytes, there was no significant difference in follicular fluid concentration of progesterone, estradiol or testosterone (see table 1). When grouped into size bins increasing by 3 $\mathrm{mm}$ diameter up to $25 \mathrm{~mm}$ (equalized to 5 groups representing ascending $20^{\text {th }}$ centiles of the study populations), it became clear that fertilization rates increased dramatically for follicles of greater than $13 \mathrm{~mm}$ (10-13 $\mathrm{mm}$ diameter- $30 \%$, 14-17 $\mathrm{mm}-62 \%)$. However, the fertilisation rates slowly declined such that the very large follicles $(>25 \mathrm{~mm})$ had a recovered oocyte fertilization rate similar to that of small follicles $(<=13 \mathrm{~mm}$ ) (see table 2).

Examining the inter-correlation of the three steroids showed interesting results (table 3): When an oocyte was present, estradiol and progesterone levels always strongly correlated with each other; however, estradiol levels did not correlate with testosterone. When an oocyte was not recovered, progesterone levels did not correlate with estradiol and testosterone, but estradiol levels did correlate with testosterone (table 3). Progesterone and testosterone did not correlate when the oocyte was fertilized, but correlated when the oocyte failed to fertilize.

\section{Discussion}

\section{Human granulosa cell biosynthesis of steroid hormone}

Using animal cell culture systems it was proposed that both theca and granulosa cells are necessary for estrogen biosynthesis, and that the major source of this was 


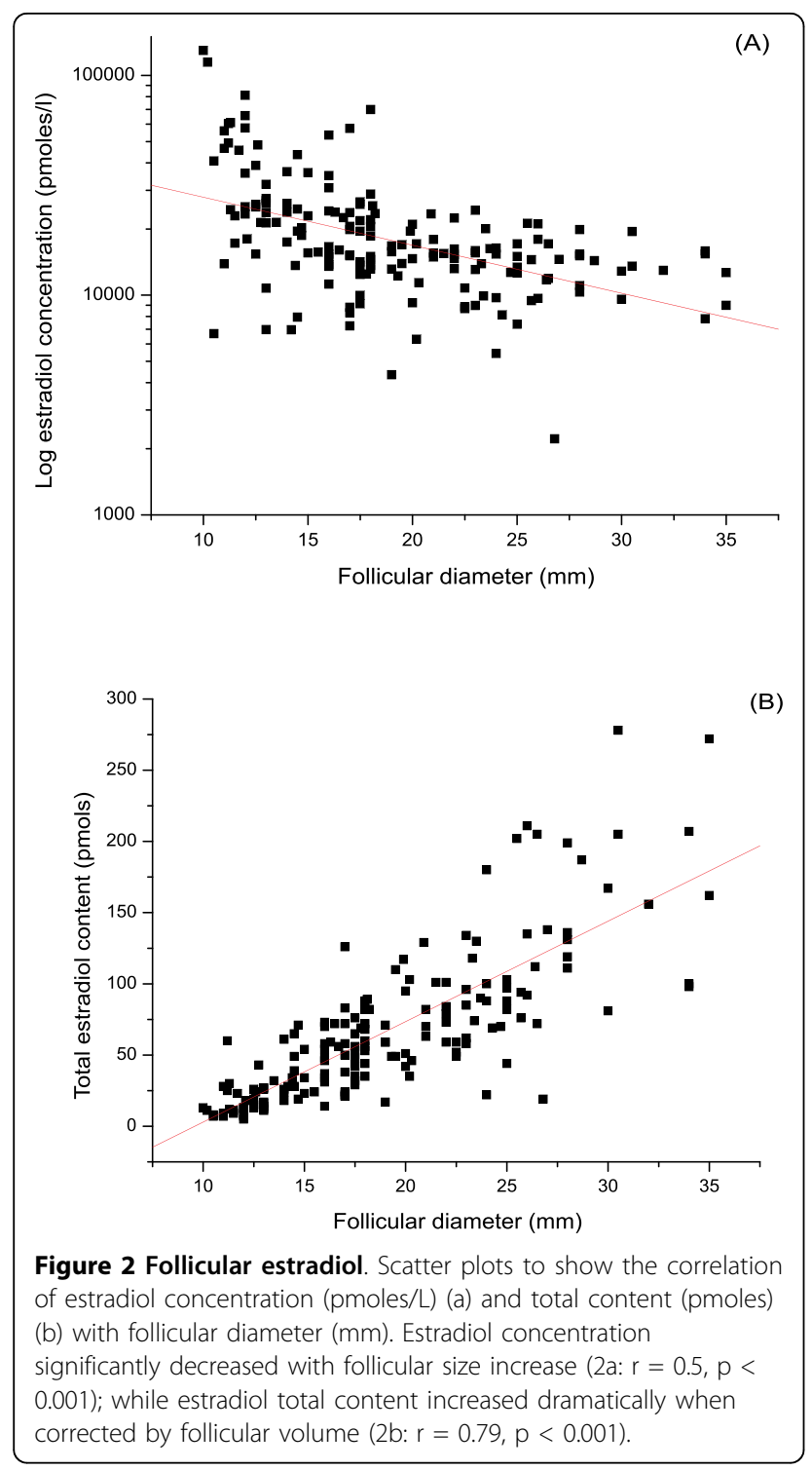

the granulosa cells [11]. As early as the 1960s, Ryan and co-workers suggested that granulosa cells are the main producer of progesterone, not estradiol $[9,10,16]$. Later on, work on monkey ovarian tissues claimed that estradiol was produced solely by theca cells [12]. According to the accepted two-cell estrogen synthesis interdependence hypothesis, the principle source of estradiol is believed to be the granulosa whereby androgens from developing follicles - derived exclusively from theca cells - are transported to the granulosa and aromatized to estradiol [17].

Our follicular fluid analysis demonstrated the presence of both estradiol and testosterone in the environment of the granulosa cells when harvested. When cultured for 24 hours and the media collected, testosterone was not detected. Estradiol, although abundant in the follicular

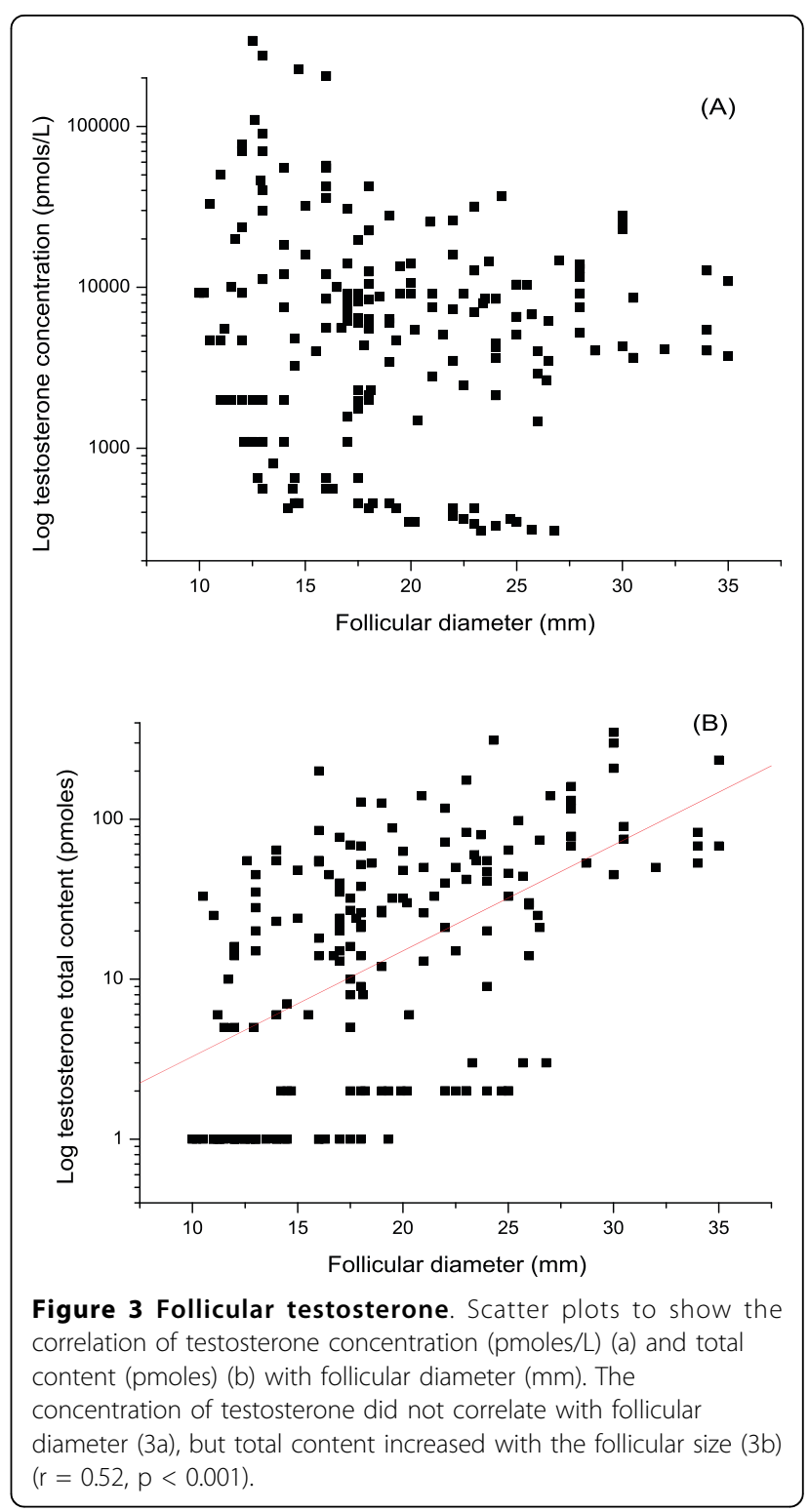

fluids, was only detected in 10 out of 121 samples. This is consistent with theca cells being the sole source of androgens, as they are the only ovarian tissue to express the enzyme P450c17/CYp17, which is responsible for converting C21 steroids (progestrogens) to C19 steroids (androgens) [18,19]. Immunohistochemical examinations of porcine follicles also showed the lack of immuneenzymatic activity of P450c17/CYP17, but highly immunodetectable levels of P450arom/CYP19 in granulosa cells [20]. Therefore, cultured granulosa cells would not be expected to synthesize estradiol unless the precursor testosterone was added. In our study, estradiol was detected in $8 \%$ of total granulosa cultured samples at low levels, which can be explained by the low levels of testosterone present in the cultures. As for the high 

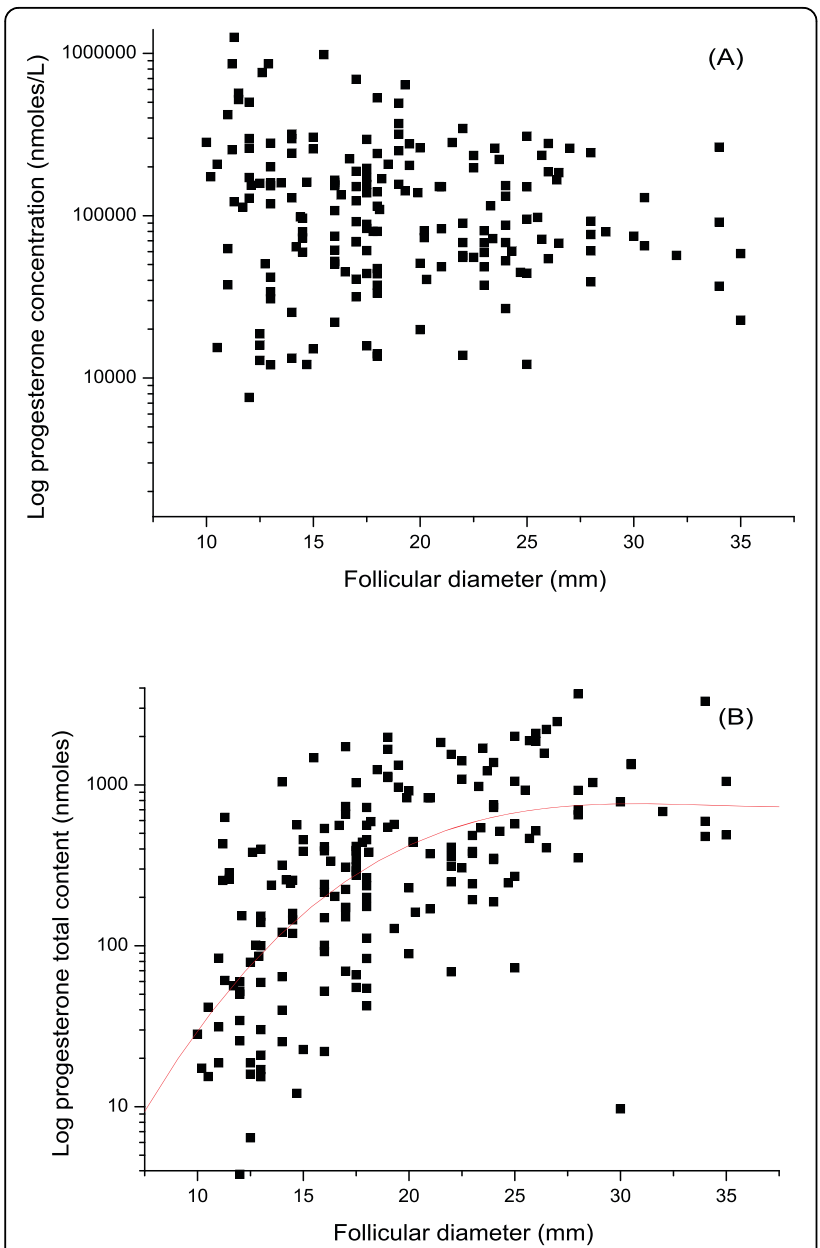

Figure 4 Follicular progesterone. Scatter plots to show the correlation of progesterone concentration (nmoles/L) (a) and total content (nmoles) (b) with the follicular diameter $(\mathrm{mm})$. The concentration slightly decreased (4a: $r=-0.15, p<0.05)$ but its total content increased with follicular size (4b: $r=0.64, p<0.0001)$.

levels of progesterone being synthesized by cultured granulosa, this can only be a consequence of upregulated $3 \beta \mathrm{HSD}$ enzymatic activity, which is induced after the gonadotropin surge. Therefore, our findings on steroid production from post luteinized cultured granulosa provide a confirmation of steroidogenic enzymes expression changes to the "two cells, two gonadotropins" model following the LH surge:

The theca is a very thin layer of cells limited to, and defining, the peripheral boundary of the follicle. These cells express CYP17 as well as $3 \beta$-HSD such that further metabolism of either pregnenolone or progesterone (via 17-OH-pregnenolone and 17-OH-pregesterone) to androgens occurs. Thereafter, androgens can diffuse across the basal lamina into granulosa cells where they can be metabolized to estrogens, since these cells specifically express CYP19/aromatase [21] (see figure 5A).
In our study, granulosa cell cultured samples were collected after 36 hours of hCG treatment and pre-oocyte retrieval, i.e. the cells were luteinized but pre-ovulatory granulosa cells. Steroidogenic ability changes under the influence of gonadotropin surge. Two previous in vitro studies of cultured granulosa cells in rats also showed the increased levels of mRNA, protein and emzymatic activity of $3 \beta-\mathrm{HSD}$ after treatment with FSH $[22,23]$. Pelletier et al have shown that 3 $\beta$-HSD was detected on both theca and granulosa cells from pre-ovulatory follicles [18]. Here we have shown high levels of progesterone detected in follicular fluids and also in 24-hour granulosa cultures; this suggests that $3 \beta \mathrm{HSD}$ is up-regulated in the luteinized granulosa cells and, since CYP17 is not expressed in this tissue, no further metabolism to androgens occurs, with progesterone becoming the major end steroid product (see figure 5B).

Post-luteinisation (which is synonymous with ovulation), the LH/FSH surge induces or up-regulates CYP11A and $3 \beta-H S D$ expression by granulosa cells such that this is now the dominant pathway and source of progesterone.

Furthermore, the important enzyme catalyzing the crucial step for the formation of either DHEA or progesterone has been shown to have two types of isoenzymes, type 1 and type 2 [24]. The specific tissue and cellular expression and substrate specificity provide to both theca and granulosa cells unique and independent mechanisms to control the levels of intracellular active steroids [25,26]. Luteinisation may induce differential expression of the two isoforms in the two cell types.

The interrelationships among the three steroids may also reveal the maturation of granulosa tissue after the gonadotropin surge (table 3). For example, in follicles from which an oocyte was not recovered, testosterone levels correlated with estradiol; perhaps this reflects the lack of granulosa maturation which requires the presence of the oocyte. When an oocyte was recovered and subsequently fertilized, estradiol correlated with progesterone levels but not testosterone.

Follicular fluid steroid hormone profiles - oocyte presence and subsequent fertilization

The relationship between follicular size and oocyte maturation has been debated for some time. Eppig et al [27] claimed that oocyte developmental competence - as shown by the ability to undergo fertilization and develop to blastocyst stage - was independent of both the size of follicle and the size of oocyte. However, the human oocyte has a size-dependent ability to resume meiosis and complete maturation: larger oocytes, or the oocytes taken from larger follicles, have a higher meiotic maturation rate [28-30]. Furthermore, McNatty et al [31] demonstrated that the hormone synthesising ability 
Table 1 Descriptive and statistical analysis of follicular fluid concentrations of estradiol, testosterone and progesterone from follicles grouped by oocyte presence and its subsequent fertilization outcome (comparisons were by the Mann-Whitney U test).

\begin{tabular}{|c|c|c|c|}
\hline Group & $\begin{array}{c}\text { Estradiol } \\
\text { Concentration (nmoles/l) } \\
\text { Median } \\
\left(25^{\text {th }}-75^{\text {th }} \text { Centile }\right)\end{array}$ & $\begin{array}{c}\text { Progesterone } \\
\text { Concentration }(\mu \text { moles } / \mathrm{l}) \\
\text { Median } \\
\left(25^{\text {th }}-75^{\text {th }} \text { Centile }\right)\end{array}$ & $\begin{array}{c}\text { Testosterone } \\
\text { Concentration (nmoles/l) } \\
\text { Median } \\
\left(25^{\text {th }}-75^{\text {th }} \text { Centile) }\right.\end{array}$ \\
\hline Oocyte & $\begin{array}{c}15.6 \\
(13.6-22.5)\end{array}$ & $\begin{array}{c}121.9 \\
(68.9-241.3)\end{array}$ & $\begin{array}{c}4.7 \\
(0.9-12.7)\end{array}$ \\
\hline No oocyte & $\begin{array}{c}19.0 \\
(12.9-51.3)\end{array}$ & $\begin{array}{c}153.7 \\
(82.2-300.2)\end{array}$ & $\begin{array}{c}9.1 \\
(0.9-24.6)\end{array}$ \\
\hline$p$ value & $p=0.33$ & $p=0.38$ & $p=0.25$ \\
\hline Fertilized & $\begin{array}{c}15.3 \\
(11.2-23.2)\end{array}$ & $\begin{array}{c}109.1 \\
(68.9-241.3)\end{array}$ & $\begin{array}{c}5.5 \\
(1.5-13.1)\end{array}$ \\
\hline Unfertilized & $\begin{array}{c}17.2 \\
(13.7-23.8)\end{array}$ & $\begin{array}{c}131.2 \\
(70.7-205.2)\end{array}$ & $\begin{array}{c}6.2 \\
(1.0-18.0)\end{array}$ \\
\hline$p$ value & $p=0.36$ & $p=0.72$ & $p=0.97$ \\
\hline
\end{tabular}

Table 2 Descriptive analysis on fertilization success rates and follicular fluid steroid concentrations of follicles grouped according to their ascending follicular size (approximately $3 \mathrm{~mm}$ incremental bins and representing $\sim 20$ centiles of the size ranked study population).

\begin{tabular}{|c|c|c|c|c|c|c|c|c|}
\hline \multirow{2}{*}{$\begin{array}{c}\text { Follicular size (mm) } \\
10-13\end{array}$} & \multirow{2}{*}{$\begin{array}{l}\mathbf{n} \\
33\end{array}$} & \multirow{2}{*}{$\begin{array}{c}\text { Percentage fertilized } \\
30 \%\end{array}$} & \multicolumn{2}{|c|}{$\begin{array}{c}\text { Progesterone concentration } \\
(\mu \mathrm{moles} / \mathrm{l}) \\
\text { NF FERT }\end{array}$} & \multicolumn{2}{|c|}{$\begin{array}{c}\text { Estradiol concentration } \\
\text { (nmoles/l) } \\
\text { NF FERT }\end{array}$} & \multicolumn{2}{|c|}{$\begin{array}{c}\text { Testosterone concentration } \\
\text { (nmoles/l) } \\
\text { NF FERT }\end{array}$} \\
\hline & & & $\begin{array}{c}128.1 \\
(34.0-282.6)\end{array}$ & $\begin{array}{c}206.9 \\
(104.3-456.7)\end{array}$ & $\begin{array}{c}25.9 \\
(19.7-52.9)\end{array}$ & $\begin{array}{c}27.2 \\
(22.5-50.9)\end{array}$ & $\begin{array}{c}9.2 \\
(2.0-32.3)\end{array}$ & $\begin{array}{c}3.4 \\
(2.0-42.5)\end{array}$ \\
\hline $14-17$ & 37 & $62 \%$ & $\begin{array}{c}142.6 \\
(51.8-159.5)\end{array}$ & $\begin{array}{c}91.8 \\
(59.7-187.6)\end{array}$ & $\begin{array}{c}23.7 \\
(17.7-30.5)\end{array}$ & $\begin{array}{c}15.9 \\
(13.6-23.2)\end{array}$ & $\begin{array}{c}1.1 \\
0.58-12.4)\end{array}$ & $\begin{array}{c}8.4 \\
(3.3-18.3)\end{array}$ \\
\hline $18-21$ & 45 & $56 \%$ & $\begin{array}{c}159.9 \\
(81.3-248.1)\end{array}$ & $\begin{array}{c}88.4 \\
(42.1-155.7)\end{array}$ & $\begin{array}{c}15.5 \\
(12.8-18.2)\end{array}$ & $\begin{array}{c}15.4 \\
(13.0-22.4)\end{array}$ & $\begin{array}{c}6.2 \\
(0.93-9.1)\end{array}$ & $\begin{array}{c}5.6 \\
(2.1-9.8)\end{array}$ \\
\hline $22-25$ & 32 & $53 \%$ & $\begin{array}{c}72.1 \\
(55.3-197.3)\end{array}$ & $\begin{array}{c}68.3 \\
(48.5-122.7)\end{array}$ & $\begin{array}{c}14.4 \\
(9.9-16.3)\end{array}$ & $\begin{array}{c}13.4 \\
(9.0-15.9)\end{array}$ & $\begin{array}{c}5.1 \\
(0.43-16.0)\end{array}$ & $\begin{array}{c}3.5 \\
(0.37-8.5)\end{array}$ \\
\hline$>25$ & 30 & $40 \%$ & $\begin{array}{c}79.5 \\
(56.9-184.3)\end{array}$ & $\begin{array}{c}76.5 \\
(58.4-235.2)\end{array}$ & $\begin{array}{c}14.4 \\
(11.8-17.1)\end{array}$ & $\begin{array}{c}13.1 \\
(9.7-15.3)\end{array}$ & $\begin{array}{c}4.2 \\
(3.4-11.9)\end{array}$ & $\begin{array}{c}8.9 \\
(4.2-12.5)\end{array}$ \\
\hline
\end{tabular}

$\mathrm{N}$ - the number of samples; NF- follicles containing an oocyte that failed to fertilize; FERT- follicles containing an oocyte that fertilized.

Table 3 Spears rank correlation analysis for the interrelationship between estradiol, progesterone and testosterone concentrations in follicular fluids from three groups: no oocyte presence, with a fertilized oocyte and with an unfertilized oocyte.

\begin{tabular}{|c|c|c|c|c|}
\hline Group & Parameter & Progesterone & Testosterone & Estradiol \\
\hline \multirow[t]{3}{*}{ No oocyte } & Progesterone & - & Rho $=-0.18$ & Rho $=0.37$ \\
\hline & Testosterone & $p=0.48$ & - & Rho $=0.54$ \\
\hline & Estradiol & $p=0.14$ & $p=0.02$ & - \\
\hline \multirow[t]{3}{*}{ Oocyte fertilized } & Progesterone & - & Rho $=0.2$ & Rho $=0.49$ \\
\hline & Testosterone & $p=0.25$ & - & Rho $=0.15$ \\
\hline & Estradiol & $p=0.003$ & $p=0.4$ & - \\
\hline \multirow[t]{3}{*}{ Oocyte non-ferilized } & Progesterone & - & Rho $=0.35$ & Rho $=0.48$ \\
\hline & Testosterone & $p=0.049$ & - & Rho $=0.13$ \\
\hline & Estradiol & $p=0.006$ & $p=0.46$ & - \\
\hline
\end{tabular}




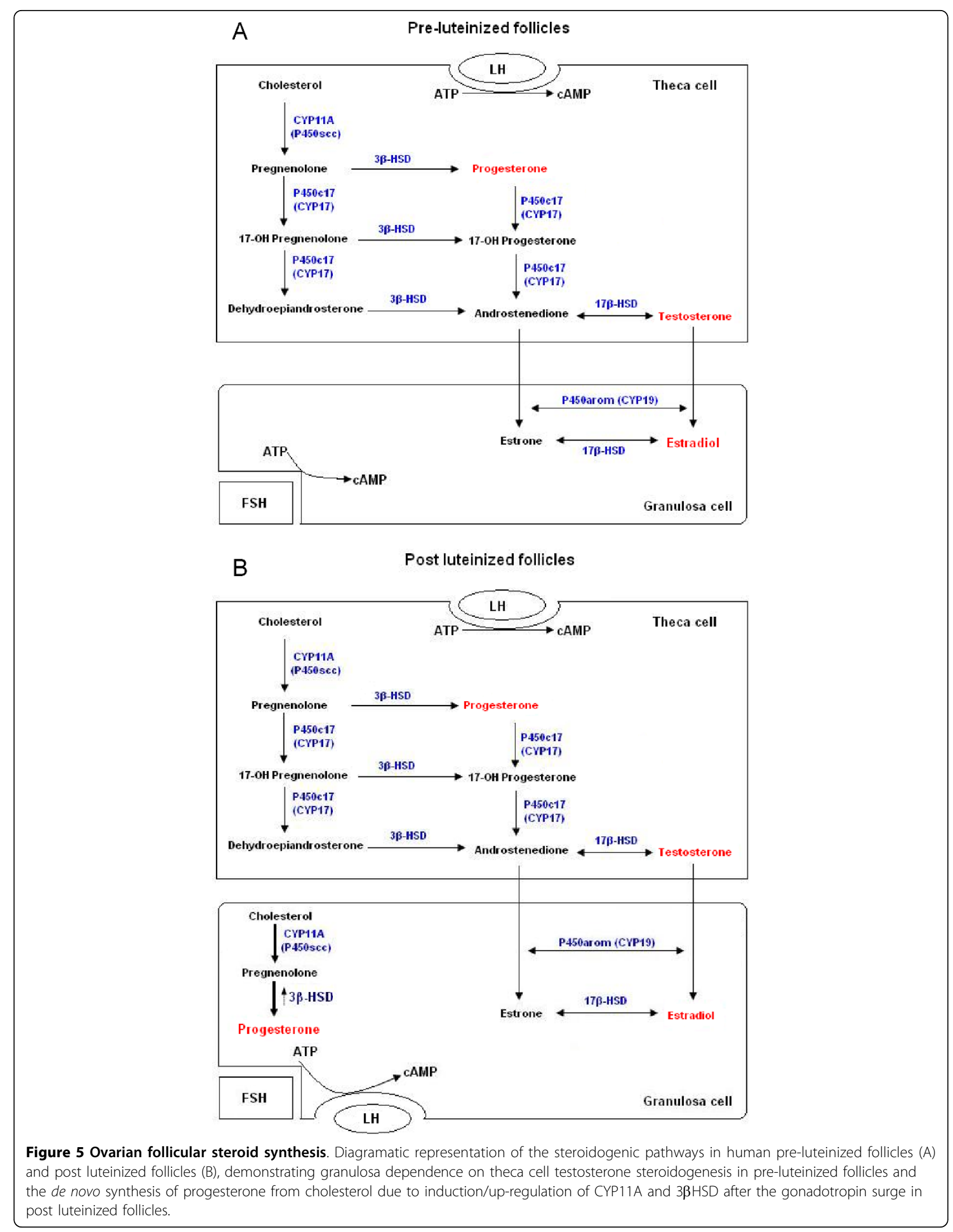


of granulosa cells was also dependent on the size of follicle from which they originated, principally in their aromatizing ability.

The fertilization and 2/4 cell blastocyst formation rate is lower for oocytes recovered from follicles of less than $<10 \mathrm{~mm}$ [32-34]. Indeed, empirical practice has shown that follicles of $18 \mathrm{~mm}$ are favored in assisted reproduction, and data now suggests that $14 \mathrm{~mm}$ is the lower end cut-off size that reflects follicular/oocyte maturity [35]. Serum estradiol is often used as a marker of follicular development $[5-7,36]$ and the steroidogenic activity of the incumbent granulosa changes with follicular maturation. Some studies have suggested that luteinized pre-ovulatory follicular fluid levels of progesterone, estradiol, testosterone - and even the ratio between estradiol and testosterone - is a better indicator of oocyte maturity than follicular size alone [37-40].

Unfortunately, most of these studies showing a significant correlation have grouped follicles into mature and immature (sometimes intermediate) by criteria based on an arbitrary follicle size cut-off. This will bias results: oocyte maturity is a function of follicular size, whilst steroid production by the follicle is also a function of follicular mass. If follicles are split simply into large (mature) or small (immature), it is inevitable that higher levels of steroids will be found in those follicles from which there was a higher rate of fertilization. Any relationship between fertilization outcome and prevailing steroid levels will be a causal function of follicle size.

In this study, we examined the molar concentrations and total content of all three steroids in individual follicles. Although most of the steroids are bound to steroid-binding proteins, they are freely released in immunoassays; as such binding has much low affinity than that of an antibody which at equilibrium obliterates the steroid protein-binding effects [41]. Therefore, the levels of three steroid hormones detected in this study reflect the total amounts of steroids. Results showed that estradiol concentration decreased (figure 2a) while its total content increased significantly with follicle size (figure 2b). Both testosterone and progesterone concentrations remained relatively constant (figure 3a, 4a), while their total content increased (figure $3 \mathrm{~b}, 4 \mathrm{~b}$ ). Thus individual steroid levels within a follicle are a function of follicular volume. Furthermore, no significant association between steroid levels and oocyte recovery or fertilization rates was found. Interestingly, fertilization rates increased dramatically from $30 \%$ for follicles not more than $13 \mathrm{~mm}$ to $62 \%$ for those between $14-17 \mathrm{~mm}$. Thereafter the fertilization rate slowly declined to $40 \%$ for those $>25 \mathrm{~mm}$ (see table 2). This suggests a postmaturity phenomenon, and thus overall this study failed to show a simple linear correlation between fertilization rates and follicular diameter. This actually further demonstrates the dominance of follicular size in any physiological relationship. This is inconsistent with a study carried out by Haines and Emes, who reported that once a follicle has reached $10-12 \mathrm{~mm}$ in diameter, the fertilization rate remained relatively constant despite progressive follicle growth [21]. This study has concentrated on follicles greater than $10 \mathrm{~mm}$ and the size of the study group would give strength to the argument that optimal follicular/oocyte maturity is $14-21 \mathrm{~mm}$.

\section{Conclusions}

For stimulated cycles, luteinized pre-ovulatory follicular fluid levels of testosterone, progesterone and estradiol do not correlate with oocyte maturity (recovery and fertilization rate). Although oocyte fertilization rates correlate with follicular size up to $\sim 21 \mathrm{~mm}$, after this the rate declines, suggesting oocyte post-maturity. In post-luteinized follicles, the steroidogenic ability of granulosa cells is altered to become the dominant cell type producing progesterone. However, these studies do suggest that the oocyte has an influence on this metabolic switching: Although progesterone is the major de novo synthesised steroid of luteinised granulosa; when an oocyte is present follicular estradiol correlates with progesterone levels. However, if an oocyte is not present follicular estradiol levels correlate with testosterone and not progesterone levels.

\section{Acknowledgements}

The authors are grateful for the financial support from Joint research board of Bartholomew's Hospital. We also appreciate the assistance from the embryologists and other staff in Fertility Centre at St. Bartholomew's Hospital. Dr XueSong Wen is the recipient of an ORS award from Universities UK.

\section{Author details}

${ }^{1}$ Biomedical Sciences, School of Health and Social Science, Middlesex University, The Burroughs, NW4 4BT, UK. ${ }^{2}$ The Williamson Laboratory, St Bartholomew's and the Royal London School of Medicine and Dentistry, Queen Mary University of London, London EC1A 7BE, UK. ${ }^{3}$ The $1^{\text {st }}$ Affiliated Hospital of Harbin Medical University, Harbin, 150001, China.

\section{Authors' contributions}

XSW and DL carried out the research and collected the data. AJT and SMD proposed the study and collected the samples. XSW and RKI performed data analysis, interpreted data. XSW drafted the manuscript, RKI and SMD made significant editing for the manuscript. All authors have read and approved the final manuscript.

\section{Competing interests}

The authors declare that they have no competing interests.

Received: 20 July 2010 Accepted: 11 October 2010

Published: 11 October 2010

\section{References}

1. Gómez E, Tarín JJ, Pellicer A: Oocytes maturation in humans: the role of gonadotrophins and growth factors. Fertil Steril 1993, 60:40-46.

2. Johnson $\mathrm{MH}$, Everitt BJ: Adult ovarian function. In Essential Reproduction. Edited by: Johnson MH, Everitt BJ. Oxford: Blackwell Science; , 5 2000:74-75.

3. Wen X, Tozer AJ, Butler SA, Bell CM, Docherty SM, lles RK: Follicular Fluid levels of Inhibin $A$, inhibin $B$ and activin $A$ levels reflect changes in 
follicle size but are not independent markers of oocyte ability to fertilize. Fertil Steril 2006, 8:1723-1729.

4. Wen X, Tozer AJ, Li D, Docherty SM, Al-Sharwaf T, lles RK: Human granulosa-lutein cell in vitro production of progesterone, inhibin-A, inhibin- $B$ and activin- $A$ are dependent on follicular size and not the presence of the oocyte. Fertil Steril 2008, 89:1406-1413.

5. Karam KS, Taymor ML, Berger MJ: Estrogen monitoring and the prevention of ovarian overstimulation during gonadotrophin therapy. Am J Obstet Gynecol 1973, 115:972-977.

6. Sckenker JG, Weinstein D: Ovarian Hyperstimulation Syndrome: a current surrey. Fertil Steril 1978, 30:255-268.

7. McArdle C, Seibel M, Hann LE, Weinstein F, Taymor M: The diagnosis of ovarian hyperstimulation (OHS): the impact of ultrasound. Fertil Steril 1983, 39:464-467.

8. Mikkelsen AL, Smith S, Lindenberg S: Impact of estradiol and inhibin A concentrations on pregnancy rate in in-vitro oocyte maturation. Hum Reprod 2000, 15:1685-1690.

9. Ryan K, Smith OW: Biogenesis of estrogens by the human ovary I. Conversion of acetate-1-C-14 to estrone and estradiol. J Biol Chem 1961, 236:705-709.

10. Ryan K, Smith OW: Biogenesis of estrogens by the human ovary. II. Conversion of progesterone-4-C-14 to estrone and estradiol. J Biol Chem 1961, 236:710-714

11. Falck B: Site of production of oestrogen on rate ovary as studied in micro-transplants. Acta Physiol Scand 1959, 474(Suppl 163):1-101.

12. Channing CP, Coudert SP: Contribution of granulosa cells and follicular fluid to ovarian estrogen secretion in rhesus monkey in vivo. Endocrinology 1976, 98:590-597.

13. Armstrong DT, Goff AK, Dorrington JH: Regulation of follicular estrogen biosynthesis. In Ovarian Follicular Development and Function. Edited by: Midgley AR and Sadler WA. New York: Raven Press; 1979:169-182.

14. Hillier SG, Whitelaw PF, Smyth CD: Follicular oestrogen synthesis: the 'two-cell, two-gonadotrophin' model revisited. Mol Cell Endocrinol 1994, 100:51-54.

15. Hillier SG: Sex steroid metabolism and follicular development in the ovary. Oxf Rev Reprod Biol 1985, 7:168-222.

16. Ryan KJ, Petro Z: Steroid biosynthesis by human ovarian granulosa and theca cells. J Clin Endocrinolo Metab 1966, 26:46-52.

17. Ojeda SR: Female Reproductive Function. In Text Book Endocrine Physiology. Edited by: Graffin JE and Ojeda SR. Oxford, New York: Oxford University Press; , 5 2004:186-225.

18. Pelletier $G$, Li S, Luu-The $V$, Tremblay Y, Bélanger A, Labrie F: Immunoelectron microscopic localization of three key steroidogenic enzymes (cytochrome P450scc, 3 $\beta$-hydroxysteroid dehydrogenase and cytochrome P450c17) in rat adrenal cortex and gonads. J Endocrinol 2001, 171:373-383

19. Payne AH, Hales DB: Overview of Steroidogenic Enzymes in the Pathway from Cholesterol to Active Steroid Hormones. Endocr Rev 2003, 25:947-970.

20. Corbin CJ, Moran FM, Vidal JD, Ford JJ, Wise T, Mapes SM, Njar VC, Brodie AM: Biochemical assessment of limits to estrogen synthesis in porcine follicles. Biol Reprod 2003, 69:390-397.

21. Haines $C J$, Emes AL: The relationship between follicle diameter, fertilization rate and microscopic embryo quality. Fertil Steril 1991, 55:205-207.

22. deMoura MD, Choi D, Adashi EY, Payne DW: Insulin-like growth factor-1mediated amplication of the follicle-stimulating hormone supported progesterone accumulation by cultured rat granulosa cells: enhancement of steroidogenic enzyme activity and expression. Biol Reprod 1997, 56:946-953.

23. Eimerl S, Orly J: Regulation of steroidogenic genes by insulin-like growth factor -1 and follicle- stimulating hormone: differential responses of cytochrome P450 side-chain cleavage, steroidogenic acute regulatory protein, and $3 \beta$ hydroxysteroid dehydrogenase/isomerase in rate granulosa cells. Bio reprod 2002, 67:900-910

24. Simard J, Ricketts ML, Gingras S, Soucy P, Feltus FA, Melner MH: Molecular biology of the 3beta-hydroxysteroid dehydrogenase/delta5-delta4 isomerase gene family. Endocr Rev 2005, 26:525-582.

25. Peltoketo H, Luu-The V, Simard J, Adamski J: 17ß-hydroxysteroid dehydrogenase (HSD)/17-ketosteroid reductase (KSR) family; nomenclature and main characteristics of the 17HSD/KSR enzymes. $J$ Mol Endocrinol 1999, 23:1-11.

26. Labrie F, Luu-The V, Labrie C, Simard J: DHEA and its transformation into androgens and estrogens in peripheral target tissues: intracrinology. Front Neuroendocrinol 2001, 22:185-212.

27. Eppig JJ, Wigglesworth K, O'Brien MJ: Developmental capacity of mouse oocytes matured in vitro effects of gonadotrophic stimulation, follicular origin and oocyte size. J Reprod Fertil 1992, 95:119-127.

28. Tsuji K, Sowa M, Nakano R: Relationship between human oocyte maturation and different follicular size. Biol Reprod 1985, 32:413-417.

29. Durinzi KL, Saniga EM, Lanzendorf SE: The relationship between size and maturation in vitro in the unstimulated human oocyte. Fertil Steril 1995, 63:404-406.

30. Whitacre KS, Seifer DB, Friedman Cl, Coskun S, Kenard KA, Kim MH, Alak BM Effects of ovarian source, patients age and menstrual cycle phase on invitro maturation of immature human oocytes. Fertil Steril 1998, 70:1015-1021.

31. MaNatty KP, Makris A, Reinhold VN, De Grazia C, Osathanodth R, Ryan K: Metabolism of androstenedione by human ovarian tissues in vitro with particular reference to reductase and aromatase activity. Steroids 1979, 34:429-443.

32. Wittmaak FM, Kreger DO, Blasco L, Tureck RW, Mastroianni L Jr, Lessey BA: Effect of follicular size on oocyte retrieval, fertilization, cleavage and embryo quality in in-vitro fertilization cycles: a 6-year data collection. Fertility and Sterility 1994, 62:1205-1210.

33. Dubey AK, Wang HA, Duffy P, Penzias AS: The correlation between follicular measurements, oocyte morphology and fertilization rates in an in vitro fertilization programme. Fertil Steril 1995, 64:787-790.

34. Salha O, Nugent D, Dada T, Kaufmann S, Levett S, Jenner L, Lue S, Sharma V: The relationship between follicular fluid aspirate volume and oocyte maturity in in-vitro fertilization cycles. Hum Reprod 1998, 13:1901-1906.

35. Teissier MP, Chable H, Paulhac S, Aubard Y: Comparison of follicle steroidogenesis from normal and polycystic ovaries in women undergoing IVF: relationship between steroid concentrations, follicle size, oocyte quality and fecundability. Hum Reprod 2000, 15:2471-2477.

36. Diamond MP, Wentz AC: Ovarian induction with human menopausal gonadotrophins. Obstet Gynecol Sun 1986, 41:480-490.

37. Ellsworth LR, Balmaceda JP, Schenken RS, Silverman AY, Prihoda TJ, Asch RH: Human chorionic gonadotrophin and steroid concentrations in human follicular fluid in relation to follicular size and oocyte maturity in stimulated ovarian cycles. Acta Eur Fertil 1984, 15:343-346.

38. Kreiner D, Liu HC, Itskovitz J, Veeck L, Rosenwaks Z: Follicular fluid oestradiol and progesterone are markers of preovulatory oocyte quality. Fertil Steril 1987, 48:991-994.

39. Artini PG, Battaglia C, D'Ambrogio G, Barreca A, Droghini F, Volpe A, Genazzani AR: Relationship between human oocyte maturity, fertilization and follicular fluid growth factors. Hum Reprod 1994, 9:902-906.

40. Mendoza C, Cremades N, Ruiz-Requena E, Martinez F, Ortega E, Bernabeu S, Tesarik J: Relationship between fertilization results after intracytoplasmic sperm injection, and intra-follicular steroid, pituitary hormone, and cytokine concentrations. Hum Reprod 1999, 14:628-635.

41. Cook B, Huntert RHF, Kelly ASL: Steroid-binding proteins in follicular fluid and peripheral plasma from pigs, cows and sheep. $J$ Reprod Fert 1977, 51:65-71.

doi:10.1186/1477-7827-8-117

Cite this article as: Wen et al.: Estradiol, progesterone, testosterone profiles in human follicular fluid and cultured granulosa cells from luteinized pre-ovulatory follicles. Reproductive Biology and Endocrinology $20108: 117$ 